\title{
Comparison of Siberian paleovegetation to current and future vegetation under climate change
}

\author{
Robert A. Monserud ${ }^{1}$, Olga V. Denissenko ${ }^{2}$, Nadja M. Tchebakova ${ }^{3}$ \\ 'Intermountain Research Station, Forest Service, United States Department of Agriculture, Moscow, Idaho 83843, USA \\ ${ }^{2}$ Department of Geography, Moscow State University, 119899 Moscow, Russia \\ ${ }^{3}$ Forest Institute, Russian Academy of Sciences (Siberian Branch), Akademgorodok, 660036 Krasnoyarsk, Russia
}

\begin{abstract}
To see if the Holocene optimum ( 4600 to $6000 \mathrm{yr}$ before present) is an analogue for predicted future climate, a comparison was made between Siberian paleovegetation for this Late Atlantic Period and predicted Siberian vegetation under climate change. Siberian paleovegetation is also compared to a current landscape map of Siberia. The Siberian Vegetation Model was used to estimate Siberian vegetation under climate change scenarios resulting from $\mathrm{CO}_{2}$ doubling. Both visual and statistical analysis of the maps indicate that the warm period known as the Holocene optimum does not provide a good analogy to predicted future warming. Although the predicted rise in temperature with future warming is similar to the Holocene optimum, the predicted precipitation is much less, resulting in much more temperate forest-steppe vegetation than the forest vegetation found in the past. Comparison of past and present vegetation revealed that most vegetation zones have not changed greatly in size or location, although species composition is quite different. Dark-needled species were widespread in the Northern and Middle Taiga in the Holocene optımum, while light-needled species now dominate these zones. Temperate broad-leaved species were a component in the Subtaiga in the mid-Holocene, whereas today they have disappeared. Tundra has greatly expanded since the Holocene optimum. These changes indicate that the current climatic regime is cooler and more severe than 4600 to $6000 \mathrm{yr}$ ago.
\end{abstract}

\section{INTRODUCTION}

Vegetation responses to climate change can be studied retrospectively by using the Quaternary fossil record (Solomon et al. 1980, Prentice 1986). Maps of long-term vegetation change based on pollen diagrams through the Late Quaternary are available for Europe (Huntley \& Birks 1983), eastern North America (Bernabo \& Webb 1977, Webb 1981, Solomon \& Webb 1985), the former USSR (Khotinsky 1984) and its western part (Peterson 1983), and the Northern Hemisphere (Frenzel et al. 1992).

The Holocene is an interglacial stage of the continuing Quaternary period. Significant post-Pleistocene climatic variations have occurred for the past 10000 to 12000 yr, a comparatively short period in the Earth's history. Postglacial warming in Siberia reached its peak during the Late Atlantic Period (Holocene optimum, mid-Holocene) at 4600 to 6000 yr before present (y.b.p.). The air temperature in the middle latitudes of the Northern Hemisphere is believed to have been 1 to $3^{\circ} \mathrm{C}$ higher than at present (Budyko 1986). How- ever, Cubasch \& Cess (1990) cite Budyko's use of the mid-Holocene as an analogue for a $1^{\circ} \mathrm{C}$ rise in global temperature. In Siberia, Frenzel et al. (1992, p. 73) show mean annual temperatures 1 to $3^{\circ} \mathrm{C}$ higher than at present, and more than $3^{\circ} \mathrm{C}$ warmer for high latitudes. Precipitation for Siberia is indicated to be from 50 to $100 \mathrm{~mm}$ higher than present by Borzenkova \& Zubakov (1984) and Frenzel et al. (1992, p. 77), except for a small island of no change in western Siberia. This period is characterized by the expansion of broadleaved temperate forests into northeastern Europe, dark-needled Taiga to the north and east in Siberia, and widespread distribution of thermophilous taxa in the forest vegetation (Khotinsky 1984). These trends are most clearly recorded in the second part of the Holocene optimum. We will concentrate on this Late Atlantic Period because it has been hypothesized to be a possible analogue to future climate change predicted from the build-up of greenhouse gases in the atmosphere (Budyko 1974, Borzenkova \& Zubakov 1984, 1985, Avenarius et al. 1987, Folland et al. 1990). Gates et al. (1990) point out that this period is probably the 
earliest in the Holocene when the boundary conditions of ice-sheet extent and sea level were analogous to the present. There is also general agreement that vegetation was close to equilibrium with the climate at this time (Gates et al. 1990). Note that several scientists reject this hypothesis of a possible analogue between past and future (e.g. Gallimore \& Kutzbach 1989, Mitchell 1990, I. C. Prentice pers. comm.) because the mechanisms of climate-forcing (orbital vs $\mathrm{CO}_{2}$ ) are very different.

Our first objective in this paper is to test if the Late Atlantic Period is an analogue for predicted future climate. We concentrate on the Siberian subcontinent. We will compare paleovegetation to possible future climate change scenarios. For past vegetation, we rely primarily on the paleovegetation map of Khotinsky (1984, p. 194-195). This is the best regional map for Siberia and was determined from newly revised ${ }^{14} \mathrm{C}$ dated palynological data. We use the Siberian Vegetation Model of Nazimova et al. (1990) and Tchebakova et al. (1993a) to estimate Siberian vegetation under $\mathrm{CO}_{2}$-doubling climate change scenarios. Our second objective is to compare vegetation in the Late Atlantic Period to the present. We use the Landscape Map of the USSR by Isachenko et al. (1988) for vegetation under current climate.

\section{METHODS}

\section{Paleovegetation classification}

Meaningful comparison of modern and paleovegetation can be made only between equivalent vegetation classes. At fine scales such as the community level this is a difficult if not impossible task because the species composition of constituent communities has likely changed with climate over 5 to 6 millennia (Prentice 1986, Huntley 1990, 1991). Huntley \& Birks (1983) used combinations of critical isopolls for both individual taxa and ecologically related groups of taxa. Pollen data can be rearranged into clusters of similar pollen spectra whose spatial extent can be mapped at a particular time. Huntley $(1990,1991)$ interpreted these clusters as broad scale vegetation units during the Holocene. The paleovegetation map can be constructed according to the distribution of pollen of one or more taxa within several time intervals to observe their spatial diffusion under climate change during the Holocene (Davis 1983).

We instead operate at a large scale, equivalent to the biome level. At such a large scale it is reasonable to assume that major biomes have survived and that their spatial distributions can be meaningfully compared, even though the species composition may have been altered (Markov \& Velichko 1964). Overpeck et al. (1985) used a similar approach to investigate the degree of analogy between modern and paleovegetation units for eastern North America. Recently Prentice et al. (1993) used modern vegetation classes to simulate the distribution of biomes on the global scale during the Last Glacial Maximum epoch (18000 y.b.p.) using general circulation models of the atmosphere.

To further support our use of modern vegetation classes to characterize paleovegetation up to 6000 y.b.p., we offer the following observations. (1) With the exception of continuing isostatic uplifting in some areas that had been under ice at the last glacial maximum (e.g. Uppsala, Sweden), the main features of the land surface such as topography and the coast line configuration have not changed significantly in the past 6000 yr. Although Fairbridge (1961) maintains that sea level was several meters higher than at present and Shepard (1964) maintains the opposite, in general the world's ocean level has varied little from the midHolocene (Kaplin 1973, Gates et al. 1990). (2) The close similarity of pollen spectra in both modern and paleovegetation classes suggests similar arboreal plant groups (Zaklinskaya 1951, Permiakov 1974, Grichuk 1984). These groups determine physiognomic features of the vegetation." (3) Vegetation has been approaching dynamic equilibrium with the climate from the past to modern times (Gates et al. 1990). The ecological demands (expressed mostly through temperature and precipitation) of arboreal taxa are similar for both modern and earlier times. The great majority of taxa have responded to the Quaternary climatic changes by migration rather than evolution (Huntley 1991).

We compiled the Siberian paleovegetation classes with the use of maps by Khotinsky $(1977,1984)$, Avenarius et al. (1987), and Frenzel et al. (1992). Our primary source was the map of Khotinsky (1984, p. 194-195). Although the density of palynological and radiocarbon sites in Siberia is not as great as in Europe or North America, there are nevertheless over 120 sites in Siberia (Fig. 1, after Khotinsky 1984). We supplemented Khotinsky's sites in Fig. 1 with 13 additional sites due to Lebkovskaya (1967), Giterman et al. (1968), Kind (1971), Koshkarova (1981), and Piavchenko (1987). Furthermore, the accuracy of the radiocarbon dates is approximately $100 \mathrm{yr}$. The resulting paleovegetation map contains 17 vegetation classes (see Fig. 2).

Tundra (including Mountain Tundra and Shrublands). During the second part of the Holocene opti-

\footnotetext{
- The use of modern vegetation classes to characterize paleo. vegetation is essentially a restatement of the principle of 'actualism', which is the basis for the whole Russian paleogeographical school (Markov \& Velichko 1967)
} 


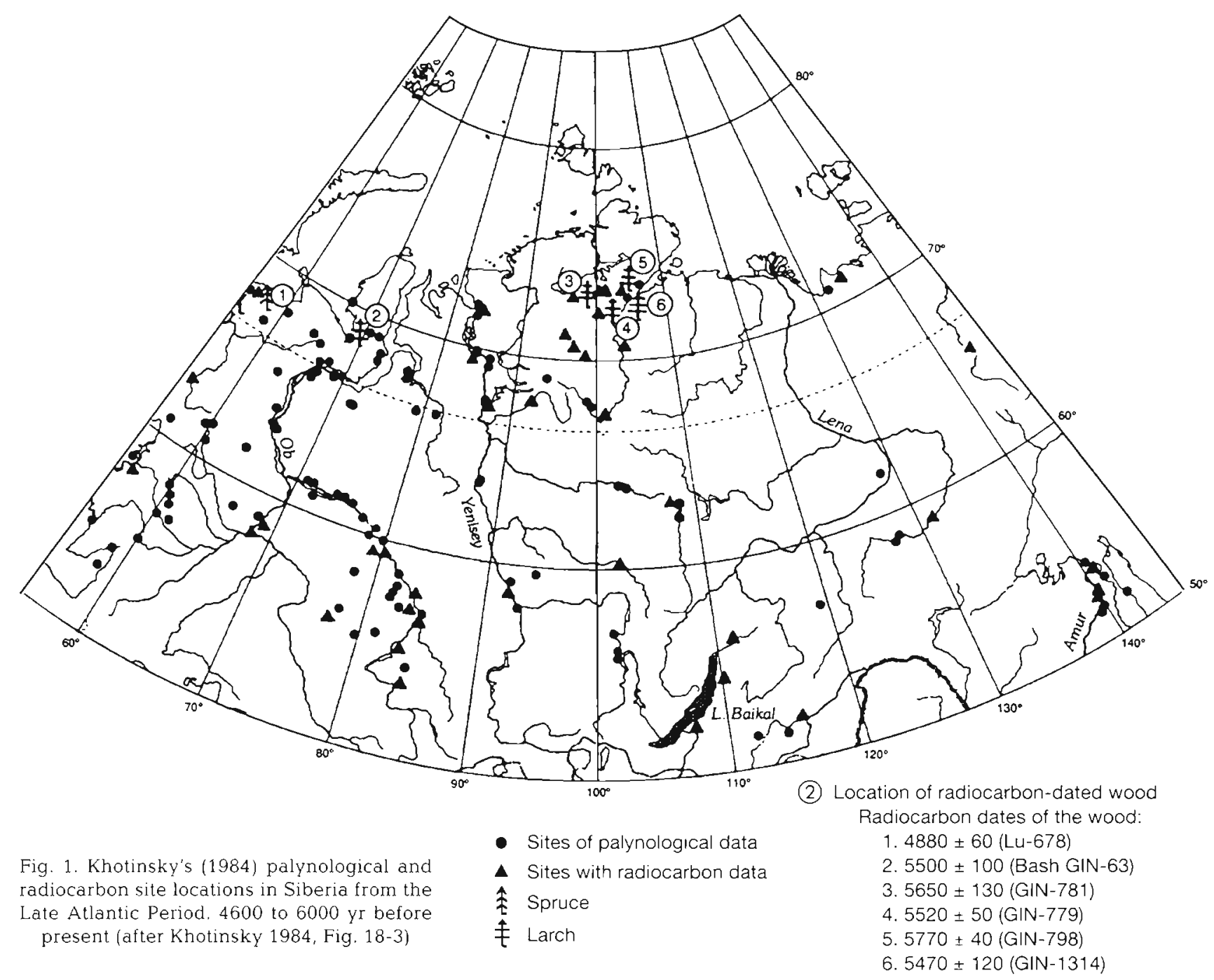

mum, Shrub Tundra occupied the areas of the modern Arctic Moss and Sedge Tundra. Betula nana was the dominant shrub in the west and Pinus pumila in the east. Because not much difference exists in general composition between modern and paleo Shrub Tundra, we can reasonably regard them as analogues.

Forest-Tundra. The western part of this zone was dominated by Betula in the tree pollen spectrum, with admixtures of Picea, Pinus sibirica, and Larix. The dominant arboreal genus in the east was Larix. Larch pollen presumably has local origin, while the presence of spruce and pine in some pollen spectra here suggests extraregional origin. In general, the vegetation of Forest-Tundra in the east could be described as Larch Open Woodland. The border between the presence of Picea in the west and dominance of Larix in the east lies at approximately $90^{\circ} \mathrm{E}$. Some areas near the Arctic coast in eastern Siberia contained Larch Open Forests; these are now Tundra.
Northern Taiga. The dominance of Picea (approximately one-third of the pollen on average) in arboreal composition was the main criterion determining Dark Coniferous Northern Taiga. The presence of sufficient quantities of Pinus and Larix pollen also shows the similarity between these paleo and modern vegetation classes. The large eastern area of Light Coniferous Taiga dominated by Larix in Khotinsky's map was subdivided into Northern Taiga and Middle Taiga using other reconstructions (Giterman et al. 1968). The end of the Atlantic Period was a time of slow transition between warming and subsequent progressive cooling at mid- to high latitudes. Since that time (4600 y.b.p.), a decline of spruce in Northern Taiga has taken place.

Middle Taiga. In the paleomap, Middle Taiga has a distinct division into Dark Coniferous (Cedar-Spruce) and Light Coniferous (Larch-Pine) with Spruce. As mentioned above, we added some parts of the Light Coniferous (Larch) Taiga to this class because in the 


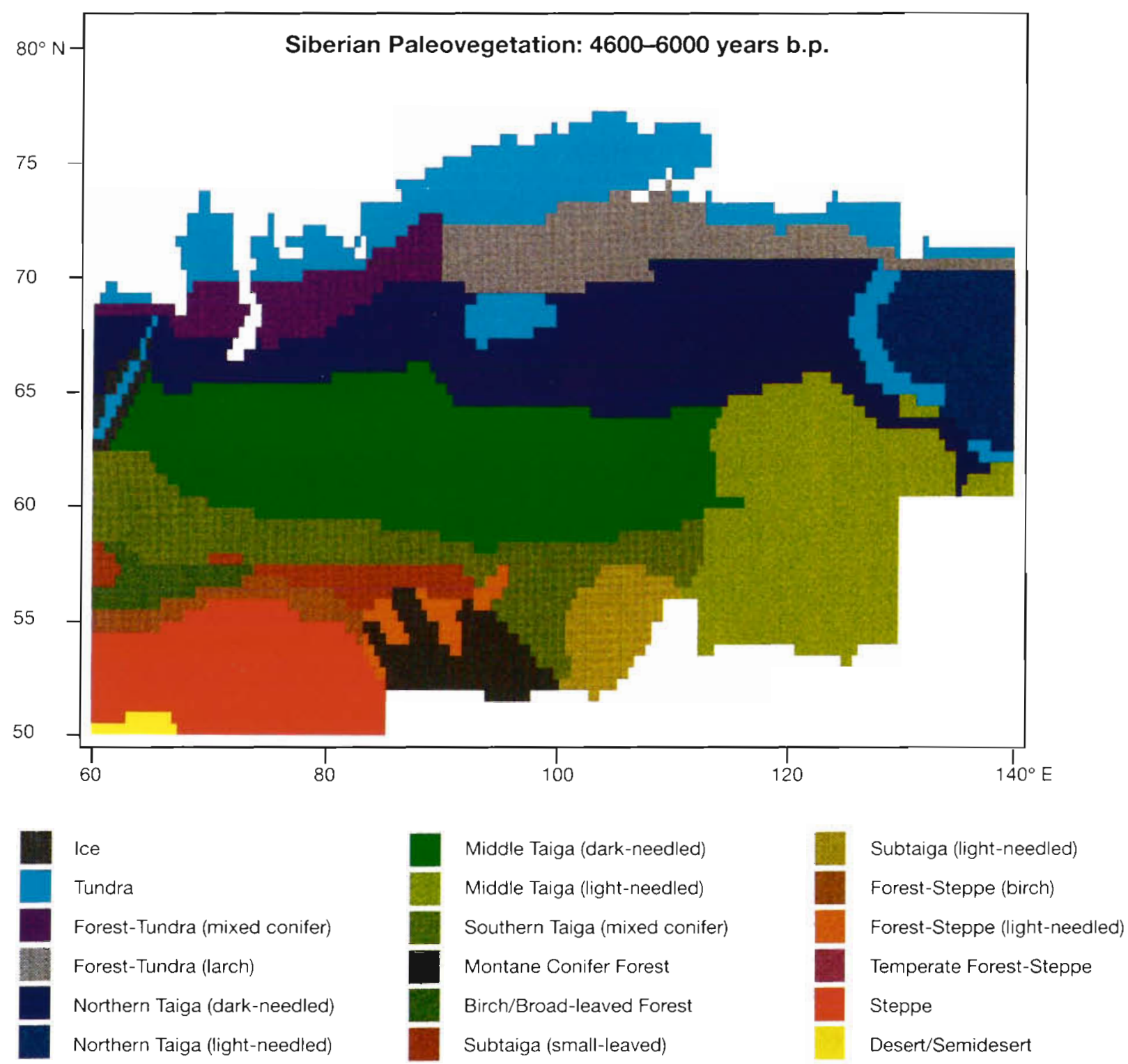

Fig. 2. Siberian paleovegetation for the Late Atlantic Period. The map is largely based on that of Khotinsky (1984, p. 194-195), with refinements due to results from Giterman et al. (1968)

reconstruction of Giterman et al. (1968) its composition is determined more definitely.

Southern Taiga. This is identified only as Dark Coniferous (Fir-Spruce with Pine Forest). The pollen spectra are characterized by the presence of Picea (which forms a constant value on the pollen diagrams during the Atlantic period), the presence of Abies, and nearly complete absence of Betula nana and $B$. exilis. These pollen spectra also contain some pollen of broadleaved temperate genera (Tilia and Ulmus), indicating an expansion of temperate taxa into this region.

Subtaiga. Within this paleovegetation zone are 3 classes: Birch Forest, Birch with Broadleaved Species, and Light Coniferous with Linden (Tilia) and Steppe.
Only a few pollen spectra typical for this zone are available from the second half of the Holocene optimum. The dominant genus for the western part of this zone was Betula, with the presence of Pinus, Pinus sibirica, and Picea noted. In central Siberia and to the east the presence of Larix and Pinus pollen and slight amounts of broadleaved genera such as Ulmus and Tilia are more characteristic.

Forest-Steppe. Khotinsky (1984) identified 3 classes of paleo Forest-Steppe in Siberia: Birch; Birch, Pine and Spruce; and Forest-Steppe with Broadleaved Species. These broadleaved species were temperate.

Steppe. Mixed-grass Mesophytic Steppe is the only Steppe vegetation class specified by Khotinsky (1984). 


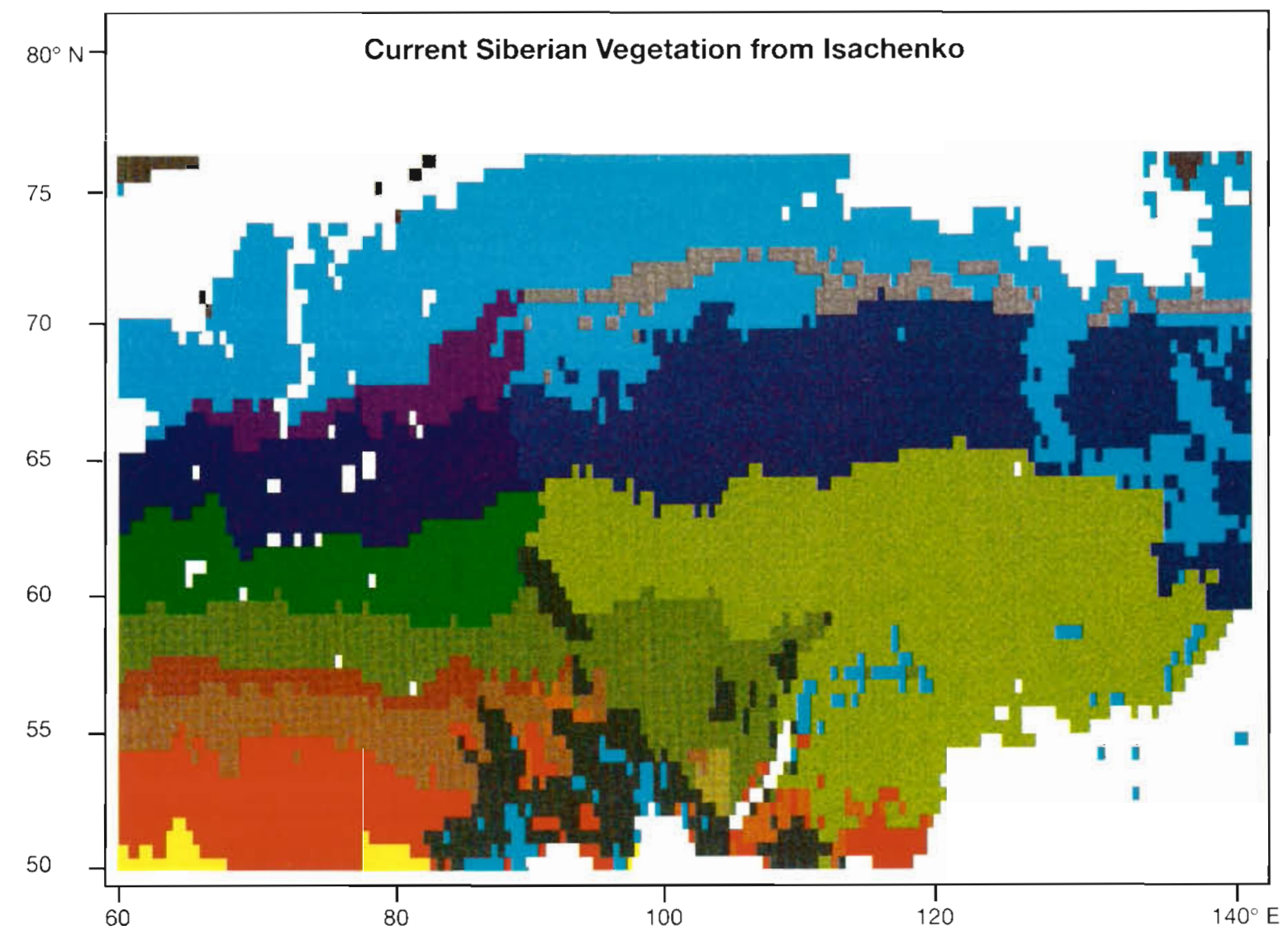

Fig. 3. Current Siberian vegetation according to the landscape map of Isachenko et al. (1988). Color scale as in Fig. 2

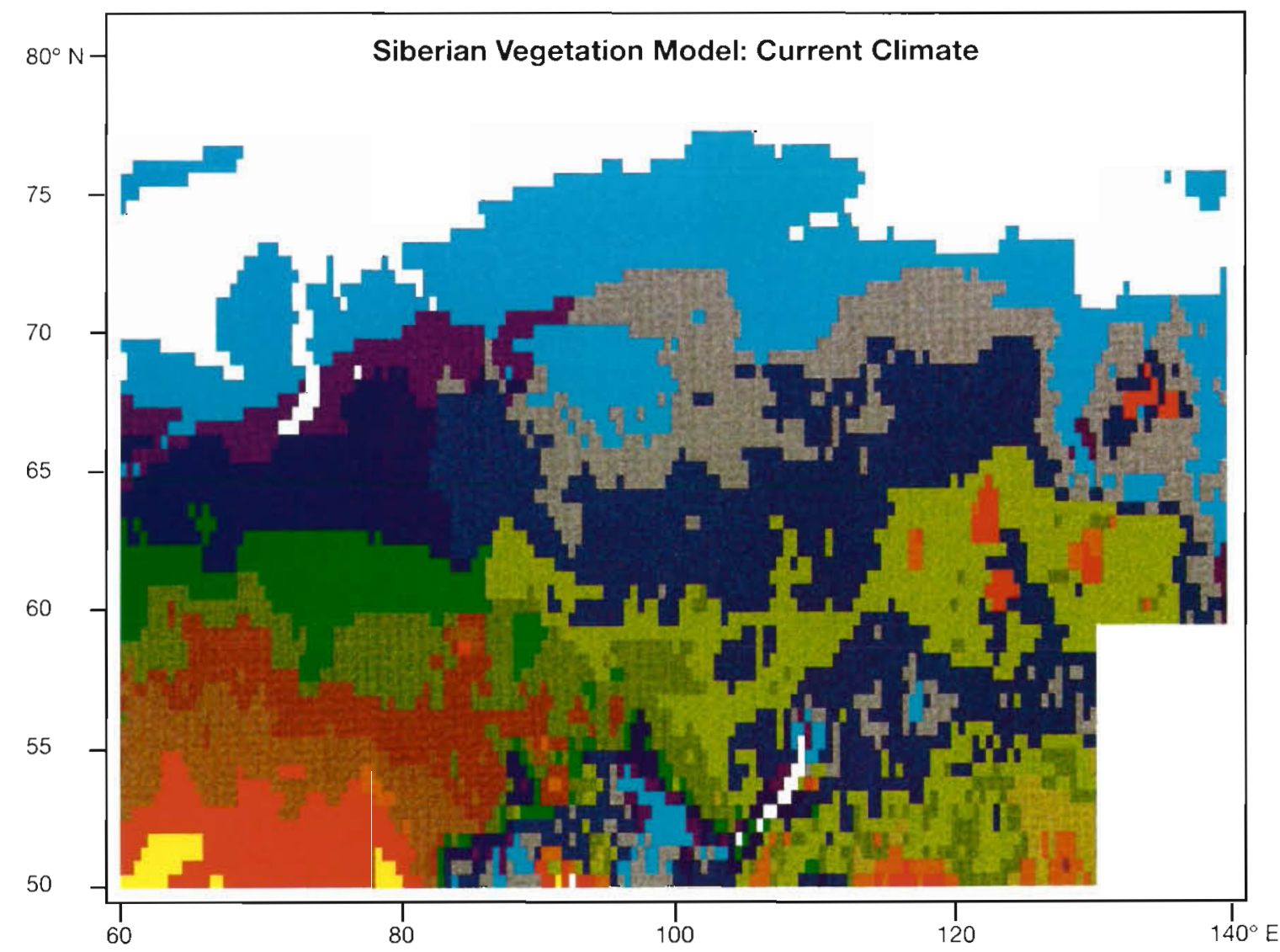

Fig. 4. Current Siberian vegetation predicted by the Siberian vegetation model of Tchebakova et al. (1993a). Color scale as in Fig. 2 
Desert/Semidesert. Siberia was bounded to the south west by a dry zone of Desert/Semidesert dominated by Artemisia and grass (Khotinsky 1984). This Semidesert zone was almost entirely in present day Kazakhstan.

Mountain Taiga. This mountain forest class is identified in the paleomap as Dark Coniferous in the northern Urals and the Altai-Sayan Mountains. Paleovegetation reconstructions in the mountain regions of Siberia remain problematic, for there is not enough information to determine which Taiga zones (Northern, Middle, or Southern) are represented and where along steep elevational gradients they grew.

\section{Modern landscape map of Isachenko}

Isachenko et al. (1988) used a 2-dimensional landscape classification formed by latitudinal thermic zones and longitudinal continentality sectors. For mountain areas, each 2-dimensional cell is developed for low, middle, and high mountain landscapes.

Isachenko et al. (1988) specify 4 zonal landscape groups for Siberia: Arctic, Subarctic, Boreal, and Subboreal (or Temperate). Within the zonal group, landscapes are subdivided by zones. Names of zones arise from dominant vegetation physiognomy. Ice, Polar Desert, and Arctic Tundra comprise the Arctic group; Tundra and Forest-Tundra form the Subarctic group; Northern Taiga, Middle Taiga, Southern Taiga, and Subtaiga make up the Boreal group; Forest-Steppe, Steppe, Semidesert, and Desert are in the Subboreal group.

Each of these zones is subdivided into 2 sectors: the continental sector in West Siberia and partly in Kazakhstan, and the extreme continental sector in East Siberia and Central Asia (the mountain systems of Altai, Sayan, and Baikal). Using an aggregation maximizing the similarities with the paleovegetation map and the climate change maps produced by the Siberian vegetation model, the resulting Isachenko map is illustrated in Fig. 3.

\section{The modified Siberian vegetation model}

Tchebakova et al. (1993a) modified the Siberian vegetation model of Nazimova et al. (1990). The result is an equilibrium model that simulates the major vegetation types of Siberia from 3 climatic parameters: growing degree-days (base $5^{\circ} \mathrm{C}$ ), dryness index, and continentality index (Table 1). Because this model is a static equi-

Table 1. Limits defining the modified Siberian model of Tchebakova et al. (1993a) for the full 24 vegetation zones. GDD 5 : growing degree-days with base $5^{\circ} \mathrm{C}$; DI: Budyko's dryness index; $\mathrm{CI}$ : Conrad's continentality index. Lower bounds are greater than or equal to the value listed, and upper bounds are less than the value listed. All zones are rectangles in space (DI, GDD 5 ), except for 2 triangular pieces: Subtaiga with corners at $(0.3,1650),(0.3,1150)$, and $(1.5,1150)$, and an additional portion of Forest-Steppe with corners at $(0.3,1650),(1.5,1650)$, and $(1.5,1150)$

\begin{tabular}{|c|c|c|c|c|c|c|}
\hline \multirow[t]{2}{*}{ Vegetation zone (and Sector) } & \multicolumn{2}{|c|}{$\mathrm{GDD}_{5}$} & \multicolumn{2}{|c|}{ DI } & \multicolumn{2}{|c|}{$\mathrm{CI}$} \\
\hline & $\begin{array}{l}\text { Lower } \\
\text { bound }\end{array}$ & $\begin{array}{l}\text { Upper } \\
\text { bound }\end{array}$ & $\begin{array}{l}\text { Lower } \\
\text { bound }\end{array}$ & $\begin{array}{l}\text { Upper } \\
\text { bound }\end{array}$ & $\begin{array}{l}\text { Lower } \\
\text { bound }\end{array}$ & $\begin{array}{l}\text { Upper } \\
\text { bound }\end{array}$ \\
\hline Tundra & 0 & 300 & None & 3.3 & None & None \\
\hline Dark-needled Forest-Tundra (Western Sector) & 300 & 500 & None & 2.0 & None & 60 \\
\hline Light-needled Forest-Tundra (Central Sector) & 300 & 500 & None & 2.0 & 60 & 85 \\
\hline Larch Forest-Tundra (Eastern Sector) & 300 & 500 & None & 2.0 & 85 & None \\
\hline Dark-needled Northern Taiga (Western Sector) & 500 & 800 & None & 2.0 & None & 60 \\
\hline Light-needled Northern Taiga (Central Sector) & 500 & 800 & None & 2.0 & 60 & 85 \\
\hline Larch Northern Taiga (Eastern Sector) & 500 & 800 & None & 2.0 & 85 & None \\
\hline Dark-needled Middle Taiga (Western Sector) & 800 & 1000 & None & 2.0 & None & 60 \\
\hline Light-needled Middle Taiga (Central Sector) & 800 & 1000 & None & 2.0 & 60 & 85 \\
\hline Larch Middle Taiga (Eastern Sector) & 800 & 1000 & None & 2.0 & 85 & None \\
\hline Dark-needled Southern Taiga (Western Sector) & 1000 & 1150 & None & 1.5 & None & 60 \\
\hline Light-needled Southern Taiga (Central Sector) & 1000 & 1150 & None & 1.5 & 60 & None \\
\hline Birch Subtaiga (Western Sector) & 1150 & 1650 & None & 1.5 & None & 60 \\
\hline Light-needled Subtaiga (Central Sector) & 1150 & 1650 & None & 1.5 & 60 & None \\
\hline Birch Forest-Steppe (Western Sector) & 1000 & 1650 & 1.5 & 2.0 & None & 60 \\
\hline Light-needled Forest-Steppe (Central Sector) & 1000 & 1650 & 1.5 & 2.0 & 60 & 80 \\
\hline Larch Forest-Steppe (Eastern Sector) & 1000 & 1650 & 1.5 & 2.0 & 80 & None \\
\hline Steppe (Western Sector) & 500 & 1650 & 2.0 & 3.3 & None & 60 \\
\hline Steppe (Central Sector) & 500 & 1650 & 2.0 & 3.3 & 60 & 80 \\
\hline Steppe (Eastern Sector) & 500 & 1650 & 2.0 & 3.3 & 80 & None \\
\hline Temperate Forest-Steppe & 1650 & None & None & 1.5 & None & None \\
\hline Temperate Steppe & 1650 & None & 1.5 & 3.3 & None & None \\
\hline Tundra-Steppe & 300 & 500 & 2.0 & 3.3 & None & None \\
\hline Semidesert/Desert & None & None & 3.3 & None & None & None \\
\hline
\end{tabular}


librium model, it can only predict the types of vegetation that are suited to the climate of a locality, not the vegetation that will actually be there. A dynamic vegetation model accurately predicting the transient response (e.g. succession and migration) is needed for the latter

Growing degree-days (Tuhkanen 1980) and the closely related concept of temperature sums used in Russian literature (see Tchebakova et al. 1993a) are widely recognized as useful parameters for characterizing the heat requirements for plants. For our study we chose growing degree-days with a base of $5^{\circ} \mathrm{C}$, the minimum temperature required for plant growth in cold climates (Prentice et al. 1992).

Dryness index (Budyko 1974) characterizes the dryness of climates. It is the ratio of annual potential evaporation to precipitation. Potential evaporation is determined from radiation balance according to the methodology of Budyko (1974), with improvements by Zubenok (1976) and Efimova (1977) (see Tchebakova et al. 1993b for details). Dryness index is strongly correlated to a ratio of actual and equilibrium evapotranspiration used by Prentice et al. (1991) to characterize drought stress in plants.

Continentality index (Conrad 1947), CI, characterizes the severity of climates arising from the size of large continents and the distance from the oceans that give rise to dominant air masses. It is a function of latitude (distance from equator) and the difference in summer maximum and winter minimum temperatures. Nazimova et al. (1990) found CI of great importance for classifying vegetation in the Siberian subcontinent.

These 3 parameters classify Siberian vegetation in 3 dimensions (see Table 1, after Tchebakova et al. 1993a). Dryness index classifies vegetation into broad zones such as Forest, Steppe, and Desert. Growing degree-days classify forest vegetation latitudinally into the following thermic subzones: Forest-Tundra, Northern, Middle, and Southern Taiga (boreal forest), Subtaiga (mixed conifer and small-leaved species), and Forest-Steppe. Forest-Steppe is additionally separated as a dryer class than Southern Taiga and Subtaiga by dryness index. Continentality index classifies vegetation into 3 longitudinally distinct sectors: the continental western sector, the more continental central sector, and the extremely continental eastern sector.

We illustrate this model in Fig. 4, primarily for visual comparison with the map of Isachenko et al. (1988); we will rely only on Isachenko for comparisons of current vegetation with past and predicted future vegetation. 'A Siberian vegetation model based on climatic parameters' by Tchebakova \& Monserud (unpubl.) should be consulted for a thorough comparison of the Siberian vegetation model predictions of current climate with the landscape map of Isachenko.

\section{Modern Siberian vegetation classification}

The primary unit of vegetation classification is the 'Zone' (e.g. Northern Taiga), equivalent to a biome. Vegetation zones are mainly separated latitudinally due to stratification by temperature. The secondary unit of classification is the 'Sector', which mainly subdivides zones longitudinally into 3 sectors of continentality and humidity. These latitudinal and longitudinal divisions are only approximate and may be interrupted by mountains. Moving west to east, there are gradients of decreasing humidity and increasing severity in the continental climate of Siberia. Continentality reaches its maximum in northern Yakutia, with the most severe climate on Earth supporting forest vegetation.

The Western Sector ( 60 to $85^{\circ} \mathrm{E}$ ) is characterized by a continental climate ( $\mathrm{CI}$ from 40 to 60 ) with relatively high humidity. This region of dark-needled Taiga (Northern, Middle, and Southern) is dominated by shade-tolerant Pinus sibirica ('cedar') and Picea obovata. Abies sibirica can also be dominant but only in southern subzones. Pinus sylvestris occurs on sandy soils and Betula pendula occurs in secondary succession stands. In Subtaiga, B. pendula and P. sylvestris are prevailing species with spruce and fir in moist valleys. Forests have sometimes been replaced by meadows because of strong anthropogenic disturbance (forest clearing, fires). The Forest-Steppe subzone is a combination of meadow Steppe, bunchgrass Steppe, and patches of Subtaiga in lower montane topography of southern Siberia. B. pendula with $P$. sylvestris are the prevailing species.

The Central Sector (approximately 85 to $120^{\circ} \mathrm{E}$ ) is both drier and more continental (CI from 60 to 85) than in the western sector. Taiga in the central sector is characterized by light-needled ('light-demanding') conifers, primarily Larix sibirica and Pinus sylvestris. Dark-needled species are generally absent, although Picea obovata occurs in river valleys and other darkneedled species may occur with increasing elevation on ridges. In Subtaiga and Forest-Steppe, Betula pendula, $P$. sylvestris, and $L$. sibirica are the dominant species.

The Eastern Sector (approximately 120 to $140^{\circ} \mathrm{E}$ ) has a climate that is extremely continental $(\mathrm{Cl}$ from 85 to $100)$ and is the driest of all 3 sectors. In fact, the larch forests of Yakutia not only are the coldest forest in the world in winter but are growing in a region that otherwise is too arid to support forest vegetation (Tchebakova et al. 1993a). These forests survive because additional moisture is available from permafrost in summer. Throughout the eastern sector, Taiga is dominated by 3 species of Larix (L. sibirica, L. gmelinii, L. cajanderii). Other conifers are absent except for Picea obovata in river valleys and Pinus sylvestris on sandy soils. No 
Southern and Subtaiga subzones exist in this sector due to the severity of the extreme continental climate. Forest-Steppe consists of mosaics of larch forests, dry steppes, and meadow steppes in lower and middle mountain elevations. L. sibirica, L. gmelinii, Betula pendula, P. sylvestris (on sandy soils), Betula dahurica, and Quercus mongolica are dominant species.

Two nonarboreal vegetation classes border forest vegetation: Tundra and Steppe. Tundra is characterized by low, scrubby vegetation that is very tolerant of cold. The mean temperature of the warmest month is between 0 and $10^{\circ} \mathrm{C}$. Steppe is characterized by xerophytic grassland and shrub communities. Although Steppe was subdivided into the same 3 sectors of continentality, the paucity of good weather records in the far north made it unreasonable to subdivide Tundra into zonality sectors, although they do exist. A third nonarboreal vegetation class is necessary to characterize the dry extremes: Desert/Semidesert, which is actually a temperate semidesert with sparse vegetation dominated by Artemisia, Anabasis and Atriplex (Belov et al. 1990).

\section{Map comparison}

We compared maps of Siberian vegetation ' corresponding to the Late Atlantic Period (see Fig. 2), current climate (see Fig. 3), and future climate change (see Figs. $5 \& 6$ ) using objective techniques described by Monserud (1990) and Monserud \& Leemans (1992). The main comparison tools were the kappa statistic (Cohen 1960) and changes in area. The kappa statistic measures pixel-by-pixel agreement between maps. We also made comparisons at a somewhat larger scale $\left(2.5^{\circ}\right.$ blocks of pixels) using a generalized kappa statistic developed by Prentice \& Monserud (Prentice et al. 1992).

We used the following 'window' to delineate Siberia: the area between $60^{\circ} \mathrm{E}$ (Ural Mountains) in the west, $140^{\circ} \mathrm{E}$ (Tchersky Mountains) in the east, $50^{\circ} \mathrm{N}$ (Mongolian border) in the south, and $75^{\circ} \mathrm{N}$ (Arctic Ocean) in the north. Because the Siberian vegetation model was not designed for maritime climates, we excluded the southeast corner of this window (the vicinity of the Sea of Okhotsk): south of $60^{\circ} \mathrm{N}$ and east of $130^{\circ} \mathrm{E}$. This Siberian window contains approximately 6900 pixels of $0.5^{\circ}$ latitude by $0.5^{\circ}$ longitude.

\footnotetext{
-We digitized Khotinsky's (1984, p. 194-195) map of the paleovegetation of Siberia and the modern landscape map of Isachenko et al. (1988) on a $0.5^{\circ} \times 0.5^{\circ}$ grid using vegetation classes specified in Table 2 . Finer divisions within Khotinsky's Taiga zones were made using results from Giterman et al. (1968)
}

Paleo, current, and predicted future vegetation can only be compared by finding a common denominator for each class in all 3 classifications. In our study this denominator is based on dominant genera, species, and physiognomy. We have aggregated classes so as to maximize the similarity between them. Table 2 gives the correspondence between paleovegetation classes of Khotinsky (1984), modern landscape classes of Isachenko et al. (1988), and Siberian model classes of Nazimova et al. (1990) and Tchebakova et al. (1993a). Because Isachenko et al. (1988) only employed 2 continentality sectors, for comparison purposes it is necessary to combine the Central and Eastern Sectors in the vegetation classification of Nazimova et al. (1990). And because the paleorecord does not support subdivisions within the broad Steppe zone, all Steppes from Isachenko and the Siberian vegetation model must be combined. There is one vegetation class in the paleovegetation record that cannot be assigned a definite analogue in the modern vegetation classification: Dark Coniferous Mountain Taiga in the northern Urals and the Altai-Sayan Mountains. Because there is not enough paleo information to determine which Taiga zones (Northern, Middle, or Southern) are represented and where along steep elevational gradients they grew, we are forced to treat these mountain areas as missing values in comparison to the Siberian vegetation model.

Tchebakova \& Monserud (unpubl.) compared their Siberian vegetation model to the landscape map of Isachenko. This was essentially a validation test, because Isachenko's map was not used for model building. They found that the patterns of vegetation predicted by the Siberian vegetation model generally match well with the vegetation patterns on Isachenko's map. The general location of all vegetation zones is also predicted correctly. This visual impression is also borne out statistically. Kappa statistics show good agreement at all scales of comparisons (from $0.5^{\circ} \times 0.5^{\circ}$ pixels to $5^{\circ} \times 5^{\circ}$ blocks of pixels) About $60 \%$ of the area in Isachenko's map is predicted to be in the same vegetation zone by the Siberian vegetation model. The most apparent discrepancies are with light-needled Northern and Middle Taiga. Isachenko's map contains a large contiguous block of light-needled Middle Taiga in eastern Siberia that is $70 \%$ larger than that predicted by the Siberia model. The model instead predicts a much larger block of light-needled Northern Taiga in central Siberia where Isachenko has Middle Taiga. A second noticeable discrepancy is the overprediction of larch Forest-Tundra. Tchebakova \& Monserud (unpubl.) speculate that the southern limits of larch ForestTundra in the Siberian vegetation model are probably not cold enough. 
Table 2. Correspondence between paleovegetation classes of Khotinsky (1984), modern landscape classes and class numbers of Isachenko et al. (1988), and the modern vegetation classes of Nazimova et al. (1990) and Tchebakova et al. (1993a)

\begin{tabular}{|c|c|c|}
\hline $\begin{array}{l}\text { Paleovegetation } \\
\text { and dominating taxa }\end{array}$ & $\begin{array}{l}\text { Isachenko's landscape classes } \\
\text { (and class numbers) }\end{array}$ & $\begin{array}{l}\text { Modern vegetation classes } \\
\text { and domunating species }\end{array}$ \\
\hline $\begin{array}{l}\text { Tundra fincluding } \\
\text { Mountain Tundra and } \\
\text { Shrublands) }\end{array}$ & $\begin{array}{l}\text { Arctic and subarctic Tundra, southern Tundra, } \\
\text { mountain desert and Tundra, mountain cold rocky } \\
\text { deserts, boreal golets, and subboreal alpine } \\
\text { meadows }(3,4,5,42-44,71,93,94)\end{array}$ & Tundra (and Tundra-Steppe) \\
\hline Forest-Tundra (spruce-larch) & $\begin{array}{l}\text { Subarctic Forest-Tundra and mountain cold rocky } \\
\text { deserts (8) west of Yakutia }\end{array}$ & $\begin{array}{l}\text { Dark-needled Forest-Tundra (Western } \\
\text { Sector); Larix sibirica, Picea obovata }\end{array}$ \\
\hline Forest-Tundra (larch) & $\begin{array}{l}\text { Subarctic Forest-Tundra and mountain cold rocky } \\
\text { deserts (8) in Yakutia }\end{array}$ & $\begin{array}{l}\text { Larch Forest-Tundra (Central and Eastern } \\
\text { Sectors); L. sibirica, yerniks, L. cajanderii }\end{array}$ \\
\hline $\begin{array}{l}\text { Dark Coniferous Northern } \\
\text { Taiga (spruce-larch) }\end{array}$ & $\begin{array}{l}\text { Boreal West Siberian and partly East Siberian } \\
\text { Northern Taiga and mountain woodlands } \\
(15,19,50)\end{array}$ & $\begin{array}{l}\text { Dark-needled Northern Taiga (Western } \\
\text { and Central Sectors); P. obovata, L. sibirica }\end{array}$ \\
\hline $\begin{array}{l}\text { Light Coniferous Taiga } \\
\text { (larch) }\end{array}$ & $\begin{array}{l}\text { Boreal East Siberian Northern Taiga, larch wood- } \\
\text { lands and elfin woods in Yakutia }(19,53,76)\end{array}$ & $\begin{array}{l}\text { Larch Northern Taiga (Eastern Sector); } \\
\text { L. cajanderii }\end{array}$ \\
\hline $\begin{array}{l}\text { Dark Coniferous Middle Taiga } \\
\text { (cedar-spruce) }\end{array}$ & Boreal West Siberian Middle Taiga (16) & $\begin{array}{l}\text { Dark-needled Middle Taiga (Western } \\
\text { Sector); Pinus sibirica, P. Obovata }\end{array}$ \\
\hline $\begin{array}{l}\text { Light Coniferous Middle Taiga } \\
\text { (larch-pine with spruce and } \\
\text { steppe) }\end{array}$ & $\begin{array}{l}\text { Boreal East Siberian Middle Taiga, mountain } \\
\text { light-needled woodlands, larch forests, and elfin } \\
\text { woodlands }(20,51,54,77)\end{array}$ & $\begin{array}{l}\text { Light-needled Middle Taiga (Central and } \\
\text { Eastern Sectors); L. sibirica, Pinus } \\
\text { sylvestris, P. obovata, L. gmelinii }\end{array}$ \\
\hline $\begin{array}{l}\text { Dark Coniferous Southern } \\
\text { Taiga (fir-spruce; pine forest) }\end{array}$ & $\begin{array}{l}\text { Boreal West and East Siberian Southern Taiga } \\
\text { partly with Subtaiga }(17,21,55)\end{array}$ & $\begin{array}{l}\text { Dark-needled Southern Taiga (Western } \\
\text { and Central Sectors); Abies sibirica, } \\
\text { P. obovata, P. sylvestris }\end{array}$ \\
\hline $\begin{array}{l}\text { Dark Coniferous Mountain } \\
\text { Forest }\end{array}$ & $\begin{array}{l}\text { Boreal West and East Siberian mountain dark- } \\
\text { needled taiga, chern taiga, and larch/cedar-larch } \\
\text { montane forests }(52,75,78,83,85)\end{array}$ & (Taiga but cannot identify zone) \\
\hline Birch Forest & Boreal West Siberian Subtaiga (18) & $\begin{array}{l}\text { Small-leaved Subtaiga (Western Sector); } \\
\text { Betula pendula, Populus tremula, } \\
\text { P. sylvestris }\end{array}$ \\
\hline Birch with Broadleaved Species & East European Subtaiga (14) & (Not identified) \\
\hline $\begin{array}{l}\text { Light Coniferous Subtaiga } \\
\text { (larch-pine with linden and } \\
\text { steppe) }\end{array}$ & $\begin{array}{l}\text { Boreal East Siberian Subtaiga in lower Angara } \\
\text { River valley }(21,55)\end{array}$ & $\begin{array}{l}\text { Light-needled Subtaiga (Central Sector); } \\
\text { P. sylvestris, L. sibirica, B. pendula }\end{array}$ \\
\hline Forest-Steppe with Birch & Boreal West Siberian Forest-Steppe (28) & $\begin{array}{l}\text { Birch Forest-Steppe (Western Sector); } \\
\text { B. pendula, Populus tremula }\end{array}$ \\
\hline $\begin{array}{l}\text { Forest-Steppe with Birch, Pine } \\
\text { and Spruce }\end{array}$ & $\begin{array}{l}\text { Subboreal West Siberian light-needled and birch } \\
\text { forests ( } 61)\end{array}$ & $\begin{array}{l}\text { Light-needled Forest-Steppe (Central and } \\
\text { Eastern Sectors); P. sylvestris, L. sibirica, } \\
\text { B. pendula, L. gmelini, L. Cajanderii }\end{array}$ \\
\hline $\begin{array}{l}\text { Forest-Steppe with } \\
\text { Broadleaved Species }\end{array}$ & $\begin{array}{l}\text { Subboreal East European typical and Southern } \\
\text { Forest-Steppe }(27)\end{array}$ & Temperate Forest-Steppe \\
\hline $\begin{array}{l}\text { Mixed-grass Mesophytic } \\
\text { Steppe }\end{array}$ & $\begin{array}{l}\text { Subboreal West Siberian and mountain Steppe } \\
(32-35,63,64)\end{array}$ & $\begin{array}{l}\text { Steppe (Boreal and Temperate; } \\
\text { all sectors) }\end{array}$ \\
\hline Desert/Semidesert & $\begin{array}{l}\text { Subboreal Semidesert and Desert, mountain dry } \\
\text { steppes and semidesert }(36-38,65-67,86-89,96)\end{array}$ & Semidesert/Desert \\
\hline
\end{tabular}

The Siberian vegetation model is rather sensitive to change in elevation (operating through growing degree-days), whereas Isachenko names vegetation classes based on the adjacent vegetation in the plains. Thus, the Siberian model simulates much more detailed regional vegetation with respect to topography. In the more mountainous eastern Siberia, this differ- ence is rather noticeable. This leads to the other obvious difference between the maps, which is the finer-scale resolution of the Siberia model map (especially in the mountains) versus the coarser scale of the Isachenko map. In central and eastern Siberia's mountainous topography, the predicted vegetation zones are of complex contours, discontinuous, and 
much more detailed than in Isachenko's map. As a result, most classes in eastern Siberia only show fair agreement with Isachenko (Tchebakova \& Monserud unpubl.).

Predictions from the Siberian vegetation model correspond rather well with Isachenko's landscape map of western Siberia, a land of gentle topography. Overall kappa statistics range from 0.60 to 0.72 , good to very good agreement. All classes in western Siberia except small-leaved Subtaiga display at least good agreement with Isachenko's map at the large scale of comparison, and most show very good agreement (Tchebakova \& Monserud unpubl.).

\section{Climatic data}

In a previous paper, Tchebakova et al. (1993a) used an improved version of the IIASA Climate Database (Leemans \& Cramer 1991) containing a global network of temperature, precipitation, and cloudiness. Humidity (or vapor pressure) was taken primarily from reference books for the former Soviet Union (Anonymous 1966-1970). We used data from about 1200 weather stations in Siberia to interpolate precipitation on $\mathrm{a} 0.5^{\circ} \mathrm{grid}$, and about 800 to 900 stations for interpolation of temperature, humidity, and cloudiness. Albedo (necessary to calculate Budyko's dryness index) was taken from Matthews' (1984, 1985) digitized albedo maps for the continents. This climatic data became input to the Siberian Vegetation model, which predicted a vegetation class for each $0.5^{\circ} \times 0.5^{\circ}$ pixel.

Climatic change scenarios are expressed in terms of temperature and precipitation using the procedure listed by Monserud \& Leemans (1992). The differences between the current climate computer control run and the doubled $\mathrm{CO}_{2}$ run are determined for a given general circulation model (GCM) of the atmosphere. These differences are interpolated from the coarser GCM grid to the finer $0.5^{\circ} \times 0.5^{\circ}$ vegetation model grid using the smooth surface fitting procedure of Leemans \& Cramer (1991). This interpolation was done for all monthly temperature and precipitation values. The 'current climate' vs 'climate change' trends were kept intact for each GCM. The absolute value of the temperature differences and the ratio of the precipitation estimates are calculated for each pixel on the finer grid. The doubled $\mathrm{CO}_{2}$ climate database is created by adding the temperature differences to the current climate database and by multiplying precipitation by the precipitation ratio. The climate change scenario is then created by using the doubled $\mathrm{CO}_{2}$ climate database as input to the Siberian vegetation model.

\section{RESULTS}

Comparisons of the paleovegetation map to current and predicted future vegetation provides a glimpse of vegetation change since the mid-Holocene optimum through the present to expected future warming (see Figs. 2, 3, $5 \&$ 6, and Table 3).

\section{Siberian paleovegetation vs Isachenko's current vegetation}

Statistical comparisons of paleo and current vegetation maps indicate fair agreement, based on kappa statistics (Monserud \& Leemans 1992, Prentice et al. 1992). Visual comparison supports this assessment (Figs. $2 \& 3$ ). This means that the general location of most zones has not changed much, especially in western Siberia (Figs. $2 \& 3$ ). However, changes for some vegetation zones were large. Poor agreement between the paleo map and Isachenko's modern map were found for dark-needled Forest-Tundra, Northern Taiga, Middle Taiga, light-needled Subtaiga, and ForestSteppe. Such poor agreement indicates that the extent and location of these zones have changed considerably in the past $6000 \mathrm{yr}$. In contrast, zones remaining fairly stable are Tundra, larch Forest-Tundra, light-needled Middle Taiga, Southern Taiga, small-leaved Subtaiga, birch Forest-Steppe, and Mountain Coniferous Forest.

The climate of the mid-Holocene in Siberia was likely warmer and milder because forest zones were widely spread and dark-needled species in the Northern and Middle Taiga penetrated much farther eastward (Figs. $2 \& 3$ ). Furthermore, the area of Tundra and Mountain Tundra was much reduced in the warmer mid-Holocene period in Siberia. The area of Mountain Tundra has doubled in the past $6000 \mathrm{yr}$. Tundra in both the plains and mountains has increased at the expense of the transitional Forest-Tundra zone and Northern Taiga. The area of Forest-Tundra has decreased by half. The area of Northern Taiga has remained the same size, although its structure was different 6000 yr ago. Dark-needled species dominated in both Northern and Middle Taiga in the mid-Holocene while light-needled species are currently much more dominant over most of Siberia. The total area of Middle Taiga was about $20 \%$ larger than now and its darkneedled sector was 3 times larger. Southern Taiga has not changed much in area. Its southern border appears to be fairly stable, occurring at approximately $57^{\circ} \mathrm{N}$ in the West Siberian plains and then following the Sayan Mountain foothills to Lake Baikal.

Birch Subtaiga has not changed in area since the mid-Holocene but has significantly changed its composition. Khotinsky (1984) showed that temperate 
Table 3. Area comparisons between the paleovegetation map of Khotinsky (1984), the current vegetation map from Isachenko et al. (1988), and 4 climate change scenarios using the Siberian vegetation model of Tchebakova et al. (1993a). The percentage of the paleovegetation zones remaining unchanged (stable areas) is also given

\begin{tabular}{|c|c|c|c|c|c|c|c|c|c|c|c|}
\hline \multirow[t]{3}{*}{ Vegetation zone } & \multirow{3}{*}{$\begin{array}{l}\text { Paleo- } \\
\text { vegetation } \\
\text { map }\end{array}$} & \multirow{3}{*}{$\begin{array}{l}\text { Are } \\
\text { Current } \\
\text { climate } \\
\text { map }\end{array}$} & \multirow{2}{*}{\multicolumn{4}{|c|}{$\begin{array}{l}\left(10000 \mathrm{~km}^{2}\right) \\
\text { Climate chanqe maps }\end{array}$}} & \multirow{3}{*}{$\begin{array}{l}\text { Current } \\
\text { climate } \\
\text { map }\end{array}$} & \multicolumn{4}{|c|}{ Percentage stable area } \\
\hline & & & & & & & & \multicolumn{4}{|c|}{ Climate change maps } \\
\hline & & & Giss & OSU & GFDL & UKMO & & GISS & OSU & GFDL & UKMO \\
\hline Tundra & 65.1 & 137.4 & 14.3 & 29.6 & 8.5 & 11.9 & 89 & 20 & 54 & 16 & 26 \\
\hline Dark-needled Forest-Tundra & 24.6 & 18.8 & 39.0 & 34.3 & 17.0 & 19.3 & 10 & 12 & 34 & 0 & 1 \\
\hline Larch Forest-Tundra & 40.1 & 16.8 & 17.5 & 22.0 & 6.5 & 1.2 & 35 & 7 & 17 & 1 & 0 \\
\hline Dark-needled Northern Taiga & 137.8 & 57.6 & 74.7 & 42.8 & 39.0 & 55.3 & 8 & 14 & 12 & 2 & 2 \\
\hline Light-needled Northern Taiga & 34.2 & 120.2 & 100.1 & 88.8 & 44.2 & 12.1 & 58 & 47 & 47 & 28 & 4 \\
\hline Dark-needled Middle Taiga & 172.1 & 57.3 & 46.8 & 33.4 & 24.9 & 41.6 & 26 & 9 & 7 & 0 & 0 \\
\hline Light-needled Middle Taiga & 133.5 & 190.6 & 81.5 & 102.2 & 46.1 & 25.4 & 87 & 18 & 15 & 1 & 1 \\
\hline Dark-needled Southern Taiga & 89.1 & 94.9 & 94.9 & 101.6 & 56.0 & 62.4 & 66 & 5 & 5 & 1 & 0 \\
\hline Small-leaved Subtaiga & 19.2 & 19.9 & 96.8 & 60.9 & 38.1 & 30.7 & 46 & 0 & 0 & 0 & 0 \\
\hline Light-needled Subtaiga & 27.2 & 3.4 & 99.3 & 118.6 & 67.9 & 110.0 & 12 & 45 & 44 & 3 & 1 \\
\hline Birch Forest-Steppe & 16.5 & 48.8 & 41.8 & 31.9 & 28.9 & 14.9 & 84 & 0 & 0 & 0 & 0 \\
\hline Light-needled Forest-Steppe & 11.1 & 3.6 & 27.4 & 67.7 & 103.2 & 47.2 & 8 & 0 & 6 & 0 & 0 \\
\hline Temperate Forest-Steppe & 0.0 & 0.0 & 120.1 & 105.1 & 330.5 & 373.1 & 0 & 0 & 0 & 0 & 0 \\
\hline Steppe & 85.6 & 73.0 & 51.5 & 62.5 & 94.1 & 59.5 & 77 & 55 & 61 & 55 & 63 \\
\hline Desert/Semidesert & 1.6 & 4.3 & 0.6 & 4.8 & 1.1 & 2.0 & 62 & 0 & 38 & 0 & 0 \\
\hline Montane Conifer Forest & 37.3 & 44.0 & 0.0 & 0.0 & 0.0 & 0.0 & 59 & 0 & 0 & 0 & 0 \\
\hline Birch/Broadleaved Forest & 14.3 & 0.0 & 0.1 & 0.1 & 0.6 & 0.0 & 0 & 0 & 0 & 0 & 0 \\
\hline
\end{tabular}

broadleaved species had penetrated into West Siberia as a component in Birch Subtaiga 4600 to 6000 y.b.p. Nowadays only a 5000 ha island of relic linden (Tilia) occurs in the foothills of the Kuznetsky Alatau, part of the Altai-Sayan Mountains (Polikarpov et al. 1986). Khotinsky also placed linden in the larch-pine class of light-needled Subtaiga just west of Lake Baikal in the mid-Holocene. Now light-needled Subtaiga still occurs near Lake Baikal but with no linden in the composition.

The transitional birch Forest-Steppe zone has tripled in size although its location at about $55^{\circ} \mathrm{N}$ has not changed much. Light-needled Forest-Steppe shown in foothills of the Altai-Sayan Mountains in the paleo map is now mostly birch Forest-Steppe. The $20 \%$ larger area of Steppe in the past and the $20 \%$ smaller area of dark-needled Mountain Forest next to Steppe indicate that climate was drier at latitudes south of $55^{\circ} \mathrm{N}$. The paleomap specifies only one Semidesert/Desert location (below $52^{\circ} \mathrm{N}$ ), which corresponds closely to the subboreal Semidesert/Desert class in Isachenko's map. In the paleomap, $50^{\circ} \mathrm{N}$ is the border between Steppe and Semidesert zones and is approximately the boundary of the ${ }^{14} \mathrm{C}$-dated paleo record; it is also the southern boundary of our Siberian window.

An expansion of Tundra and Mountain Tundra and a considerable expansion in light-needled components of Northern and Middle Taiga indicate that by modern times cooling had occurred within high latitudes of Siberia. The stable location of Southern Taiga indicates the southern limit of the cooling expansion.
Moreover, precipitation in all these zones did not decrease so much as to cause Steppe to advance into Forest. However, at lower latitudes reduced areas of Forest-Steppe and the enlarged Steppe provide evidence that the paleoclimate was drier in southern Siberia.

\section{Siberian paleovegetation vs predicted future vegetation}

Some researchers are optimistic that climate during the Holocene optimum might be an analogue for climate under $\mathrm{CO}_{2}$-induced global warming (e.g. Budyko 1974, Borzenkova \& Zubakov 1984, 1985. Avenarius et al. 1987). We have examined this hypothesis for the Siberian subcontinent by comparing the paleovegetation map at 4600 to 6000 y.b.p. with vegetation maps drawn by the Siberian vegetation model when coupled with GCM global warming scenarios (Tchebakova et al. 1993a). We used climate change projections corresponding to a doubling of $\mathrm{CO}_{2}$ from the following 4 GCMs: GFDL, Geophysical Fluid Dynamics Laboratory of NOAA at Princeton (Wetherald \& Manabe 1986, Manabe \& Wetherald 1987); GISS, Goddard Institute for Space Studies of NASA at Columbia University (Hansen et al. 1983); OSU, Oregon State University at Corvallis (Schlesinger \& Zhao 1989); and UKMO. United Kingdom Meteorological Office (Mitchell 1983, Wilson \& Mitchell 1987). 


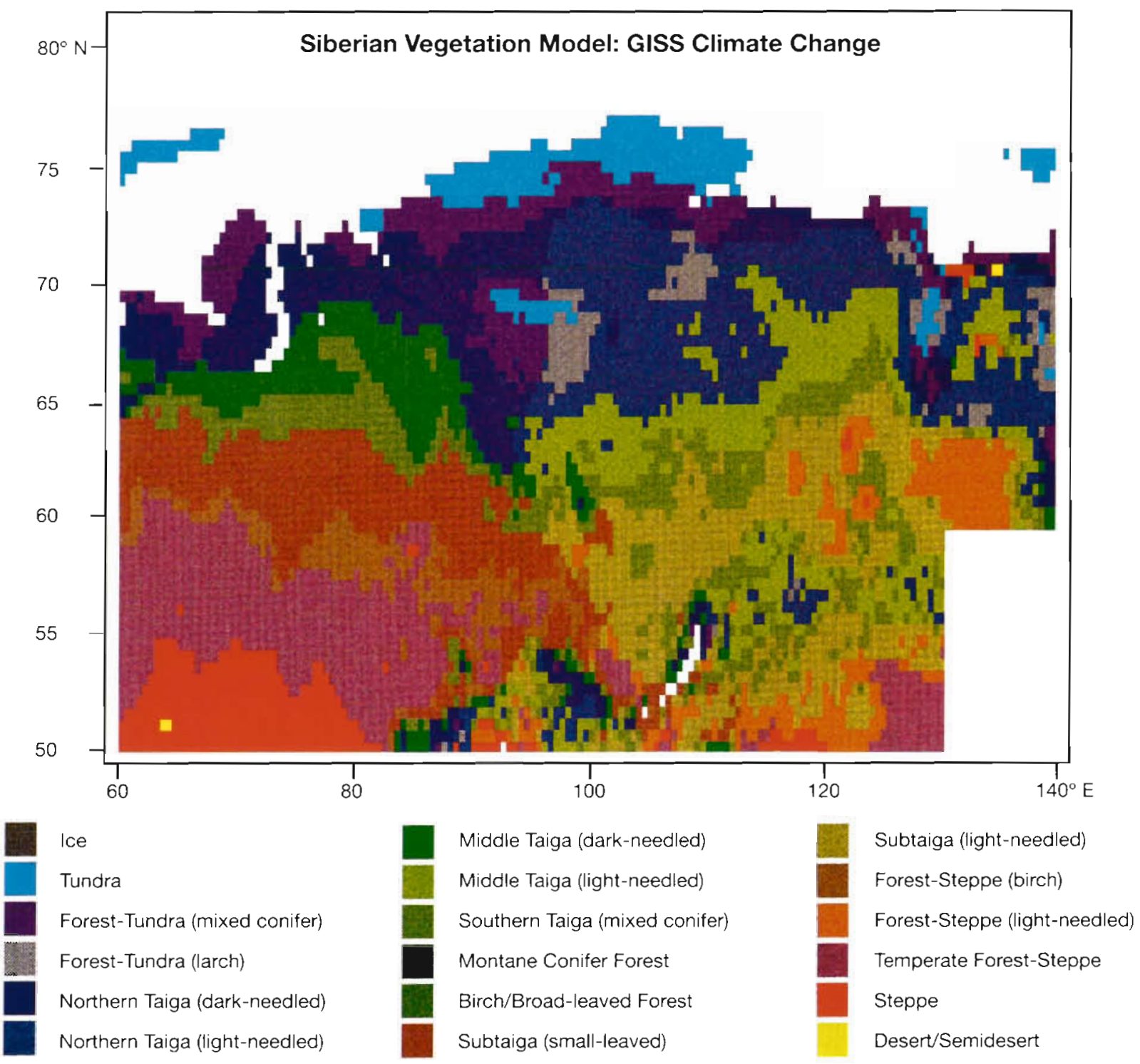

Fig. 5. Predicted Siberian vegetation using the Siberian vegetation model (Tchebakova et al. 1993a) and the $\mathrm{CO}_{2}$-doubling scenario from the GISS model

Monserud \& Leemans (1992) found that similar results for predicting vegetation could be obtained from GFDL and UKMO, and from OSU and GISS. We found that observation correct for the Siberia model also.

The OSU and GISS scenarios predict moderate warming (Table 3). The kappa statistic shows very poor agreement between paleo and future vegetation, indicating little in common between the maps. The future Taiga forest zone appears to be considerably larger than that predicted from the GFDL and UKMO scenarios but still $30 \%$ smaller than on the paleo map. For example, Middle Taiga is predicted by both scenarios to be situated farther northward and more than 2 times smaller in area. However, Northern Taiga according to the GISS prediction would cover a territory on the future map $25 \%$ larger than that on the paleo map (Figs. $2 \& 5$ ). This indicates that the warming in the northern latitudes will not be as severe as predicted by the GFDL and UKMO scenarios. The area occupied by Middle and Southern Taiga in the past would be occupied by drier Subtaiga with future climate change scenarios. The area of future Subtaiga and Forest-Steppe would increase 3 times, while the transitional Forest-Steppe zone is predicted to double. About half of the Steppe zone would remain in the same location although it is predicted to decrease in area by a third. The predicted warming apparently will not be accompanied by sufficient precipitation to support forest vegetation in current Steppe regions. 


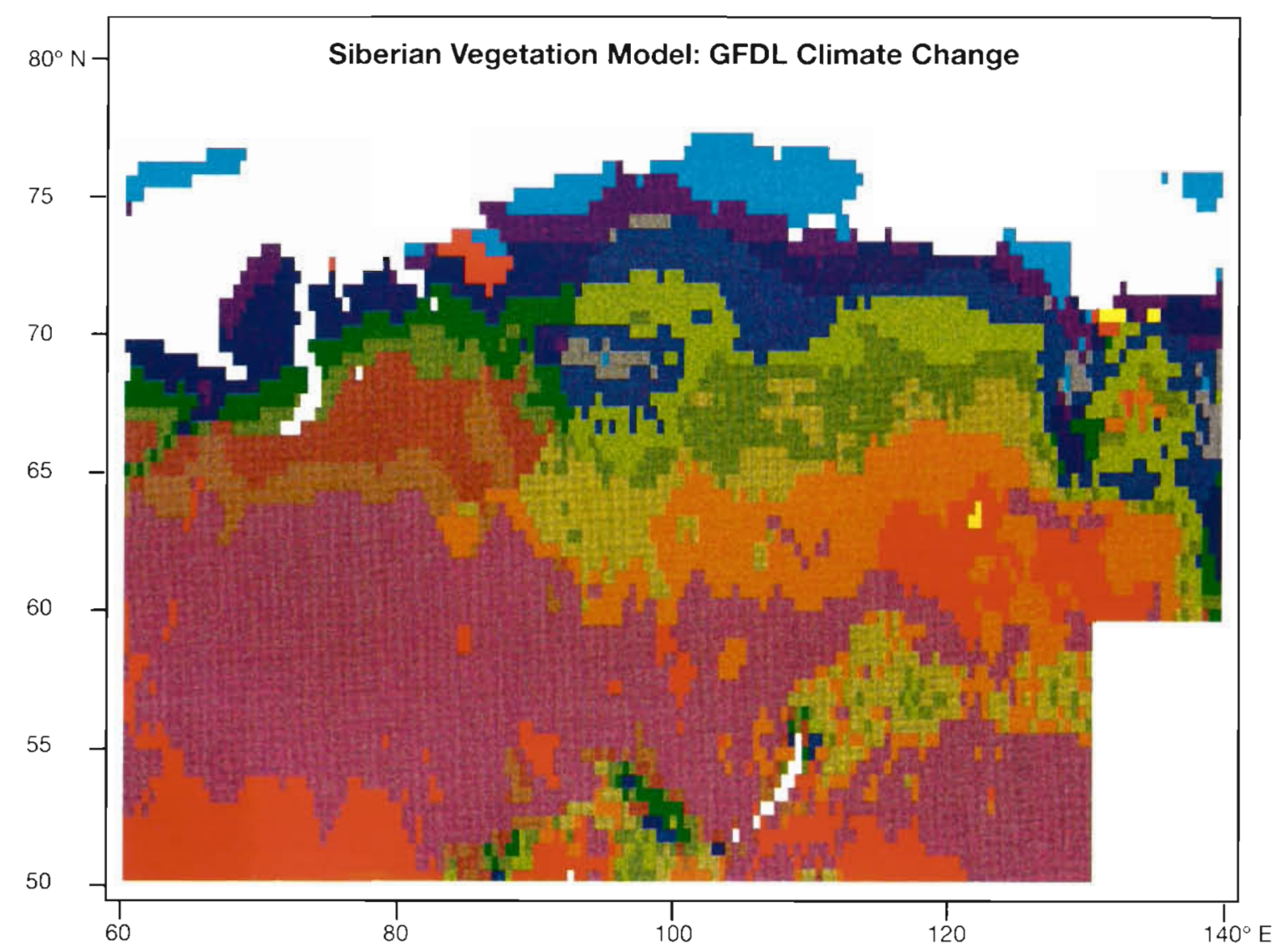

Fig. 6. Predicted Siberian vegetation using the Siberian vegetation model (Tchebakova et al. 1993a) and the $\mathrm{CO}_{2}$-doubling scenario from the GFDL model. Color scale as in Fig. 5

The GFDL and UKMO scenarios predict extreme warming (Table 3). The comparison of vegetation maps indicates that vegetation predicted by the GFDL and UKMO scenarios shows no agreement with paleovegetation. The distribution and areas of the vegetation classes were completely different (Figs. 2 \& 6). Tundra together with Mountain Tundra would be drastically smaller than in the past. Predicted Taiga forest vegetation would occur in a region north of 63 to $65^{\circ} \mathrm{N}$, while paleo Taiga forest vegetation was spread across almost the entire Siberian subcontinent above 53 to $55^{\circ} \mathrm{N}$. The predicted Northern and Middle Taiga area is 3 to 4 times smaller than in the past. The drier Subtaiga and Forest-Steppe are predicted to be 2 to 4 times larger in area. The future Temperate ForestSteppe transition zone would be the major vegetation class. In fact, temperate vegetation would dominate the entire southern half of Siberia in these $\mathrm{CO}_{2}$ doubling scenarios. In the past, Forest-Steppe was represented as a narrow band situated far to the south; in future scenarios it occupies much of the former location of Middle Taiga. The only class predicted to have any stability is Steppe. It is predicted to dominate southwestern Siberia as in the mid-Holocene, but also to expand as far as eastern Siberia. This comparison shows that these GCM scenarios simulate the future climates warmer and significantly drier than those of the past.

\section{DISCUSSION}

Natural vegetation zonation results from a correspondence between climatic factors such as warmth and moisture availability and the distributions of adapted plants (Dokuchaev 1900, Köppen 1936. Holdridge 1947 . Budyko 1974). Climatic factors mediated through light, heat, and water directly affect biochemical and physiological processes in plants (Woodward 1987) and indirectly influence the distribution of plants by affecting competition and genetic adaptation (Grigoriev 1954, Grigoriev \& Budyko 1956). According to the paleontological record, the major features of modern vegetation zones (biomes) in the high and middle latitudes of the Northern Hemisphere have been established since the last glacial retreat (Velichko 1984, Frenzel et al. 1992). 
Climate change since the mid-Holocene could cause changes in the spatial distribution of these large vegetation zones and their areas and borders but not in the main zonal vegetation physiognomy (Markov \& Velichko 1967). Several studies in the former USSR have found good correlations between modern zonal vegetation and the modern sporo-pollen spectra (Zaklinskaya 1951, Permiakov 1974, Grichuk 1984). Although the resolution of the resulting paleovegetation maps is coarse, the maps are important for a comparison between paleo, modern, and future vegetation. These maps facilitate understanding of relationships between vegetation and climate at broad spatial and temporal scales, although such maps do not specify population and community composition (Clark 1992).

Our objective was to examine the possibility that the Holocene climatic optimum (Late Atlantic Period) expressed through vegetation might be an analogue for projected climate change under $\mathrm{CO}_{2}$-doubling. We focus on Siberia. Budyko $(1974,1986)$ drew the parallel between a 1 to $3^{\circ} \mathrm{C}$ rise in expected future and past temperature regimes in middle latitudes of the Northern Hemisphere. Likewise, Borzenkova \& Zubakov (1984) studied temperature deviations for the Holocene climatic optimum and future global warming and found they were similar. Also focusing on similarities in the temperature regimes, Avenarius et al. (1987, p. 62) state that the Holocene climatic optimum is a reliable analogue for future expected greenhouse warming. Using the Siberian vegetation model in conjunction with several GCM projections of future climate change, we failed to find an analogy between the 2 periods. Although the temperature regimes were indeed similar as Borzenkova \& Zubakov (1984), Budyko (1974, 1986), and Avenarius et al. (1987) point out, the moisture regimes were much different. The Holocene climatic optimum was a period of high humidity, resulting in conditions ideal for forest growth, especially dark-needled species. In contrast, the future climate projections of global warming present a Siberia that is much drier with more severe climates. Resulting vegetation maps are rather different, except for southern vegetation zones that were also dry in the Late Atlantic Period. The distribution of forest vegetation requiring more moisture (e.g. Taiga) was quite different in the 2 maps

These results are consistent with the observations and findings of COHMAP members (1988), who point out that the climate forcing dominating the past 18000 years was due to orbital changes, while the forcing predicted to bring future climate change is due to a build-up of greenhouse gases. These are fundamentally different mechanisms (Mitchell et al. 1990). resulting in circulation and precipitation patterns different from those projected for $\mathrm{CO}_{2}$ doubling. Mitchell
(1990) simulated climatic change corresponding to these 2 mechanisms and found they predicted different climates. The orbitally induced mid-Holocene simulation predicted climates with much larger seasonal and latitudinal variation than found in the $\mathrm{CO}_{2}$-doubling climate predictions.

\section{Caveats}

Several possible sources of error in this analysis could affect results to varying degrees. First is the difficulty of accurately reconstructing the paleovegetation from a sparse paleontological record, especially in the mountains, which has already been discussed. Second, it is easy to think of the landscape map of Isachenko as an exact description of the current vegetation, but it is actually a rather abstract cartographic model. A difficulty occurs with the choice of major zones for labeling mountain forest vegetation, for they are chosen as if the mountains were not present. For example, the vegetation west of Lake Baikal is labeled Southern Taiga because it is a visual continuation of the Southern Taiga zone that stretches westward across Siberia. However, mountains are present, and as a result of harsher climates in higher elevations, the actual forest vegetation of this area is Middle Taiga or Northern Taiga. This problem also results from the scale of the map (1:4000000). It is thus impossible to accurately depict strong elevational gradients in mountains, even though Isachenko's map is $2 \mathrm{~m}$ wide

A third possible source of error is that the Siberian vegetation model is needed to make climate change predictions, and being based on only 3 climatic parameters it is not perfect. Tchebakova \& Monserud (unpubl.) compared the current climate prediction from the Siberian vegetation model to available vegetation maps for Siberia, primarily Isachenko et al. (1988). They found that the patterns of vegetation predicted by the Siberian vegetation model generally match well with the vegetation patterns on Isachenko's map. The general locations of all vegetation zones are predicted correctly. This visual impression is also borne out statistically, with kappa statistics showing good agreement at all scales of comparison. This close correspondence was found even though Isachenko's landscape map is large scale and significantly generalized, while the Siberian vegetation model simulates rather detailed regional vegetation, especially in mountains.

And fourth, errors in the GCMs could affect results. The validation of GCMs showed that they produce reIiable global distributions of temperature and precipitation, which are the main driving variables in the vegetation model. At regional scales, GCMs produce significant errors in these variables in all models exam- 
ined (Houghton et al. 1990). With improvements in the GCMs, particularly in predictions of regional patterns of precipitation, we should get better predictions of future vegetation distribution under climate change.

\section{CONCLUSIONS}

Both visual and statistical analysis of the vegetation maps reveal that the warm period known as the Holocene optimum does not provide a good analogy in Siberia to predicted future warming resulting from $\mathrm{CO}_{2}$ doubling. Although the predicted rise in temperature with future warming is similar to the Holocene optimum, the predicted precipitation is much less, resulting in much more temperate Forest-Steppe vegetation than Forest-Taiga vegetation found in the past. Comparisons with the map of the paleovegetation at 4600 to 6000 y.b.p. demonstrate the favorable combination of warmth and moisture for expanded forest growth within the Boreal zone. Comparison of past and present vegetation revealed that most vegetation zones have not changed greatly in size or location, although species composition is quite different. Darkneedled species dominated the Northern and Middle Taiga in the Holocene optimum, while light-needled species now dominate these zones. Temperate broadleaved species were a component in Subtaiga in the mid-Holocene, whereas today they have disappeared. Tundra has greatly expanded since the Holocene optimum. The dominance of dark-leaved species in Taiga, the presence of temperate species in Subtaiga, and the reduced Tundra area in the Late Atlantic Period all indicate that the current climatic regime is cooler and more severe than 4600 to 6000 yr ago.

Acknowledgements. We are indebted to Nick Crookston for writing the color mapping program. We are grateful to Rik Leemans for providing the climate change scenarios and to Wolfgang Cramer for supplying the updated version of the IIASA climate database. We thank Al Solomon and Colin Prentice for providing helpful review comments and Doug Fox (U.S.D.A. Forest Service Global Change Research Program) for providing research support.

\section{LITERATURE CITED}

Anonymous (1966-1970). Reference books on climate of the USSR, Vol. II, Issues 17 \& 20 to 24 . Hydrometeoizdat, Leningrad (in Russian)

Avenarius, I. G., Muratova, M. V., Spasskaya, I. I. (1987). Paleogeography of the North Eurasia during the Late Glacial-Holocene and geographical prognosis. Nauka, Moscow (in Russian)

Belov, A. V., Gribova, S. A., Karamysheva, Z. V., Kotova, T. V. (eds.) (1990). Vegetation of the USSR. General Ministry of Geodesy and Cartography (GUGK) of the USSR, Minsk (in Russian)
Bernabo, J. C., Webb, T III (1977). Changing patterns in the Holocene pollen record of northeastern North America: a mapped summary. Quat. Res. 8: 64-69

Borzenkova, I. I., Zubakov, V. A. (1984). Climatic optimum of the Holocene as a model of the global climate at the beginning of the 21st Century. Meteorol. Gidrolog. 8: 69-77 (in Russian)

Borzenkova, I. 1., Zubakov, V. A. (1985). The climatic optimum of the Holocene as an analogue of the climate of the 21 st mid-century. Proceedings of the Main Hydrological Institute. Issue 339. Gidrometeoizdat, Leningrad, p. $93-118$ (in Russian)

Budyko, M. I. (1974). Climate and life. Academic press, New York

Budyko, M. I. (1986). The evolution of the biosphere. D Reidel Publishing Company, Dordrecht

Clark, J. M. (1992). Paleoecological perspectives on modeling broad scale responses to global change. In: Kareiva, P. M., Kingsolver, J. G., Huey, R. B. (eds). The University of Washington. Sinauer Associates, Sunderland, MA, p. 315-332

Cohen, J. (1960). A coefficient of agreement for nominal scales. Educ. psychol. Meas. 20: 37-46

COHMAP Members (Cooperative Holocene Mapping Project) (1988). Climatic changes of the last 18,000 years: observations and model simulations. Science 241. $1043-1052$

Conrad, V (1947). Usual formulas of continentality and their limits of validity. Trans. Am. geophys. Un. 27(5): 663-664

Cubasch, U., Cess, R. D. (1990). Processes and modelling. In: Houghton, J. T., Jenkins, G. J., Ephraums, J. J. (eds.) Climate change: the IPCC scientific assessment. Cambridge University Press, Cambridge, p. 69-91

Davis, M. B. (1983). Quaternary history of deciduous forest of eastern North America and Europe. Ann. Mo. Bot. Gard. 70: $550-563$

Dokuchaev, V V. (1900). Zones naturelles des sols. In: The study of natural zones. Geogratgizdat, Moscow (republished 1948, in Russian)

Efimova, N. A. (1977). Radiation factors of vegetation productivity. Hydrometeoizdat, Leningrad (in Russian)

Fairbridge, R. W. (1961). Eustatic changes in sea level. Phys Chem. 4: 64-69

Folland, C. K., Karl, T R., Vinnikov, K. Ya. (1990). Observed climate variations and changes. In: Houghton, J. T., Jenkins, G. J.. Ephraums, J. J. (eds.) Climate change: the IPCC scientific assessment. Cambridge University Press, Cambridge, p. 199-238

Frenzel, B., Pésci, M., Velichko, A. A. (eds) (1992). Atlas of paleoclimates and paleoenvironments of the Northern Hemisphere (Late Pleistocene-Holocene). Geographical Research Institute of Hungarian Academy of Sciences, Budapest. Gustav Fischer Verlag, Stuttgart

Gallimore, R. G., Kutzbach, J. E. (1989). Effects of soil moisture on the sensitivity of a climate model to Earth orbital forcing at 9000 yr BP. Clim. Change 14: 175-205

Gates, W. L., Rowntree, P. R., Zeng, Q.-C. (1990). Validation of climate models. In: Houghton, J T., Jenkins, G. J., Ephraums, J. J. (eds.) Climate change: the IPCC scientific assessment. Cambridge University Press, Cambridge, p. $97-130$

Giterman, R. E., Golubeva, L. V., Zaklinskaya, E. D., Koreneva, E. V., Matveeva, O. V., Skiba, L. A. (1968). The main development stages of the vegetation of North Asia during the Anthropogen. Trudy Geologicheskogo Instituta 17. Nauka, Moscow (in Russian)

Grichuk, V. P. (1984). Late Pleistocene vegetation history. In Velichko, A. A. (ed.) Late Quaternary environments of the 
Soviet Union. University of Minnesota Press, Minneapolis, p. $155-178$

Grigoriev, A. A. (1954). Geographical zonation and some of its regularities. Bulletin of the Soviet Academy of Sciences, USSR, Geographical Series, 5: 17-39 (in Russian)

Grigoriev, A. A., Budyko, N. I. (1956). On the periodical law of geographical zonation. Doklady AN SSSR (Proceedings of the Soviet Academy of Sciences) 1: 151-154 (in Russian)

Hansen, J., Russell, G., Rind, D., Stone, P., Lacis, A., Lebedeff, S., Reudy, R., Travis, L. (1983). Efficient three-dimensional global models for climate studies: Models I and II. Mon Weath. Rev. 3(4): 609-662

Holdridge, L. R. (1947). Determination of world plant formations from simple climatic data. Science 105: 367-368

Houghton, J. T., Jenkins, G. J., Ephraums, J. J. (eds.) (1990). Climate change: the IPCC scientific assessment. Cambridge University Press, Cambridge

Huntley, B. (1990). European post-glacial forest: compositional changes in response to climatic change. J. Veg. Sci. 1: $507-518$

Huntley, B. (1991). How plants respond to climate change: migration rates, individualism and the consequences for plant communities. Ann. Bot. 67 (Suppl. 1): 15-22

Huntley, B., Birks, H. J. B. (1983). An atlas of past and present pollen maps for Europe $0-13000$ years ago. Cambridge University Press, Cambridge

Isachenko, A. G., Shlyapnikov, A. A., Robozertseva, O. D. Filipetskaya, A. Z. (1988). The landscape map of the USSR. General Ministry of Geodesy and Cartography (GUGK) of the USSR, Moscow (4 parts, in Russian)

Kaplin, P. A. (1973). The modern history of the World's ocean coasts. Moscow Univ. Publishing House, Moscow (in Russian)

Kind, N. V (1971). Geochronology of the Late Plesstocene based on isotope data. Nauka, Moscow, p. 257 (in Russian)

Khotinsky, N. A. (1977). Holocene of the Northern Eurasia. Nauka, Moscow (in Russian)

Khotinsky, N. A. (1984). Holocene vegetation history. In Velichko, A. A (ed.) Late Quaternary environments of the Soviet Union. University of Minnesota Press, Minneapolis, p. $179-200$

Koshkarova, V. L. (1981). The history of the taiga forests development within Yenisey sector of Siberia (based on paleocarpology). In: Paleobotanik study in the forest of the Northern Eurasia. Nauka, Novosibirsk, p. 3-30 (in Russian)

Köppen, W. (1936). Das Geographische System der Klimate. In: Köppen, W., Geiger, R. (eds.) Handbuch der Klimatologie, Vol. 1, Part C. Gebrüder Borntraeger, Berlin

Lebkovskaya, T. M. (1967). Regularities of the pollen and spore distribution in the modern and Holocene deposits of West Siberia. Abstract of a Ph.D. dissertation, Leningrad State University (in Russian)

Leemans, R., Cramer, W. (1991). The IIASA database for mean monthly values of temperature, precipitation and cloudiness of a global terrestrial grid. Res. Pap. RR-91-18. International Institute for Applied Systems Analysis, Laxenburg, Austria, p. 105-122

Manabe, S., Wetherald, R. T (1987). Large-scale changes in soil wetness induced by an increase in carbon dioxide, J. atmos. Sci. 44: 1211-1235

Markov, K. K., Velichko, A. A. (1967). Quaternary period (Glacial period-Anthropogenic period). Nedra, Moscow (in Russian)

Matthews, E. (1984). Vegetation, land-use and seasonal albedo data sets. NASA Technical Memorandum 86107. Goddard Institute for Space Studies, New York
Matthews, E. (1985). Atlas of archived vegetation, land-use and seasanal albedo data sets. NASA Technical Memorandum 86199. Goddard Institute for Space Studies, New York

Mitchell, J. F. B. (1983). The seasonal response of a general circulation model to changes in $\mathrm{CO}_{2}$ and sea temperature Q. J. R. Meteorol. Soc. 109: 113-152

Mitchell, J. F. B. (1990). Greenhouse warming: is the midHolocene a good analogue? J. Clim. 3(11): 1177-1192

Mitchell, J. F. B., Manabe, S., Meleshko, V., Tokioka, T (1990). Equilibrium climate change and its implications for the future. In: Houghton, J. T., Jenkins, G. J., Ephraums, J. J. (eds.) Climate change: the IPCC scientific assessment. Cambridge University Press, Cambridge, p. 135-164

Monserud, R. A. (1990). Methods for comparing global vegetation maps. WP-90-40. International Institute for Applied Systems Analyses, Laxenburg, Austria

Monserud, R. A., Leemans, R. (1992). The comparison of global vegetation maps. Ecol. Modelling 62: 275-293

Nazimova, D. I., Polikarpov, N. P., Tchebakova, N. M. (1990) Climatic ordination of forest vegetation zones and vertical belts as a basis for the general classification of the forest cover of Siberia. Proc. Int. Symp. 'Boreal forests: state, dynamics and anthropogenic impacts'. Forest State Committee Press, Arkhangelsk-Moscow

Overpeck, J. T., Webb, T III, Prentice, I. C. (1985). Quantitative interpretation of fossil pollen spectra: dissimilarity coefficients and the method of modern analogs. Quat. Res 23: $87-108$

Permiakov, A. I. (1974). Peculiarities of the formation of sporopollen spectra of the modern continental sedimentary deposits. Quaternary geology and geomorphology of the West Siberia lowland. In: Proceedings of the Institute of Geology, Vol. 25. Siberian Branch of the USSR Academy of Sciences, Novosibirsk, p. 82-91 (in Russian)

Peterson, G. M. (1983). Holocene vegetation and climate in the western USSR. Ph.D. thesis, University of Wisconsin, Madison

Piavchenko, N. 1. (1987). Paleogeographical studies of the northern part of West Siberia during the Holocene. In: Holocene palynology. Nauka, Moscow, p. 64-67 in Russian)

Polikarpov, N. P., Tchebakova, N. H., Nazimova, D. (1986). Climate and montane forests in southern Siberia. Siberian Division, Academy of Sciences of the USSR, Novosibirsk (in Russian)

Prentice, I. C. (1986). Vegetation responses to past climatic variation. Vegetatio 67: 131-141

Prentice, I. C., Cramer, W., Harrison, S. P., Leemans, R. Monserud, R. A., Solomon, A. M. (1992). A global model based on plant physiognomy and dominance, soil properties and climate. J. Biogeogr. 19: 117-134

Prentice, I. C., Sykes, M. T., Cramer, W. (1991). The possible dynamic response of northern forests to global warming. Global Ecol. Biogeogr. Lett. 1: 129-135

Prentice, I. C., Sykes, M. T., Lautenschlager, M., Harrison, S. P., Denissenko, O., Bartlein, P. J. (1993). Modelling the increase in terrestrial carbon storage after the last glacial maximum. Global Ecol. Biogeogr. Lett. (in press)

Schlesinger, M. E., Zhao, Z. C. (1989). Seasonal climatic changes induced by doubled $\mathrm{CO}_{2}$ as simulated by the OSU atmospheric GCM/mixed-layer ocean model. J. Clim. 2: $459-495$

Shepard, E. P. (1964). Sea level changes in the past 6000 years, possible archeological significance. Science 143: 171-179

Solomon, A. M., Delcourt, H. R., West, D. C., Blasing, T J. (1980). Testing a simulation model for reconstruction of prehistoric forest-stand dynamics. Quat. Res. 14: 275-293 
Solomon, A. M., Webb, T III (1985). Computer-aided reconstruction of Late-Quaternary landscapes dynamics. A. Rev. Ecol. Syst. 16: 63-84

Tchebakova, N. M., Monserud, R. A., Leemans, R., Nazimova, D. 1. (1993a). Possible vegetation shifts in Siberia under climatic change. In: Leemans, R, Elder, O., Pernetta, J (eds.) Impacts of climate change on ecosystems and species. Chapman and Hall, New York (in press)

Tchebakova, N. M., Monserud, R. A., Leemans, R., Golovanov, S. V. (1993b). A global vegetation model based on the climatological approach of Budyko. J. Biogeogr. 20: $129-144$

Tuhkanen, S. (1980). Climatic parameters and indices in plant geography. Acta Phytogeogr. Suec. 67: 1-110

Velichko, A. A. (ed.) (1984). Late Quaternary environments of the Soviet Union. University of Minnesota Press, Minneapolis

Editor: G. Esser
Webb, T. III (1981). The past 11,000 years of vegetational change in eastern North America. BioSci. 31:501-506

Wetherald, R. T, Manabe, S. (1986). An investigation of a cloud cover change in response to thermal forcing. Clim. Change 8: 5-23

Wilson, C. A. Mitchell, J. F. B. (1987). A doubling $\mathrm{CO}_{2}$ climate sensitivity experiment with a global climate model including a simple ocean. J. geophys. Res. 92: 13315-13343

Woodward, F. I. (1987). Climate \& plant distribution. Cambridge University Press, New York

Zaklinskaya, E. D. (1951). Materials for the study of the composition of modern vegetation and its sporo-pollen spectra for the purposes of the biostratigraphy of the Quaternary deposits (broadleaved and mixed forests). USSR Academy of Sciences, Geology Series, 127(48): 74-128 (in Russian)

Zubenok, L. I. (1976). Evaporation on the continents. Gidrometeoizdat, Leningrad (in Russian)

Manuscript first received: May 25, 1993

Revised version accepted: September 23, 1993 